\title{
A STRATEGY FOR MONITORING GLACIERS
}

Circular 1132

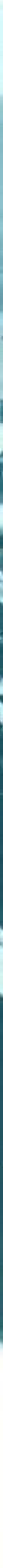

$$
\text { (2) }
$$

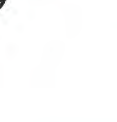

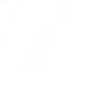

\section{A STRATEGY FOF
U.S. Geological Survey \\ A STRATEGY FOF
u.s. Geological Survey}

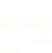

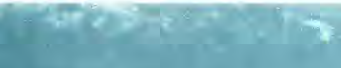


COVER PHOTOGRAPH: Glaciers near Mount Shuksan and Nooksack Cirque, Washington. Photograph 86R1-054, taken on September 5, 1986, by the U.S. Geological Survey. 


\section{A Strategy for Monitoring Glaciers}

By Andrew G. Fountain, Robert M. Krimmel, and Dennis C. Trabant 


\title{
U.S. DEPARTMENT OF THE INTERIOR BRUCE BABBITT, Secretary
}

\author{
U.S. GEOLOGICAL SURVEY
}

Gordon P. Eaton, Director

The use of firm, trade, and brand names in this report is for identification purposes only and does not constitute endorsement by the U.S. Government

U.S. GOVERNMENT PRINTING OFFICE：1997

\author{
Free on application to the \\ U.S. Geological Survey \\ Branch of Information Services \\ Box 25286 \\ Denver, CO 80225-0286
}

\author{
Library of Congress Cataloging-in-Publications Data \\ Fountain, Andrew G. \\ A strategy for monitoring glaciers / by Andrew G. Fountain, Robert M. Krimmel, and Dennis C. Trabant. \\ p. $\quad \mathrm{cm}$. -- (U.S. Geological Survey circular ; 1132) \\ Includes bibliographical references (p. - ). \\ Supt. of Docs. no.: I 19.4/2: 1132 \\ 1. Glaciers--United States. I. Krimmel, Robert M. II. Trabant, Dennis. III. Title. IV. Series. \\ GB2415.F68 1997 \\ 551.31 ' 2 --dc21
}




\section{CONTENTS}

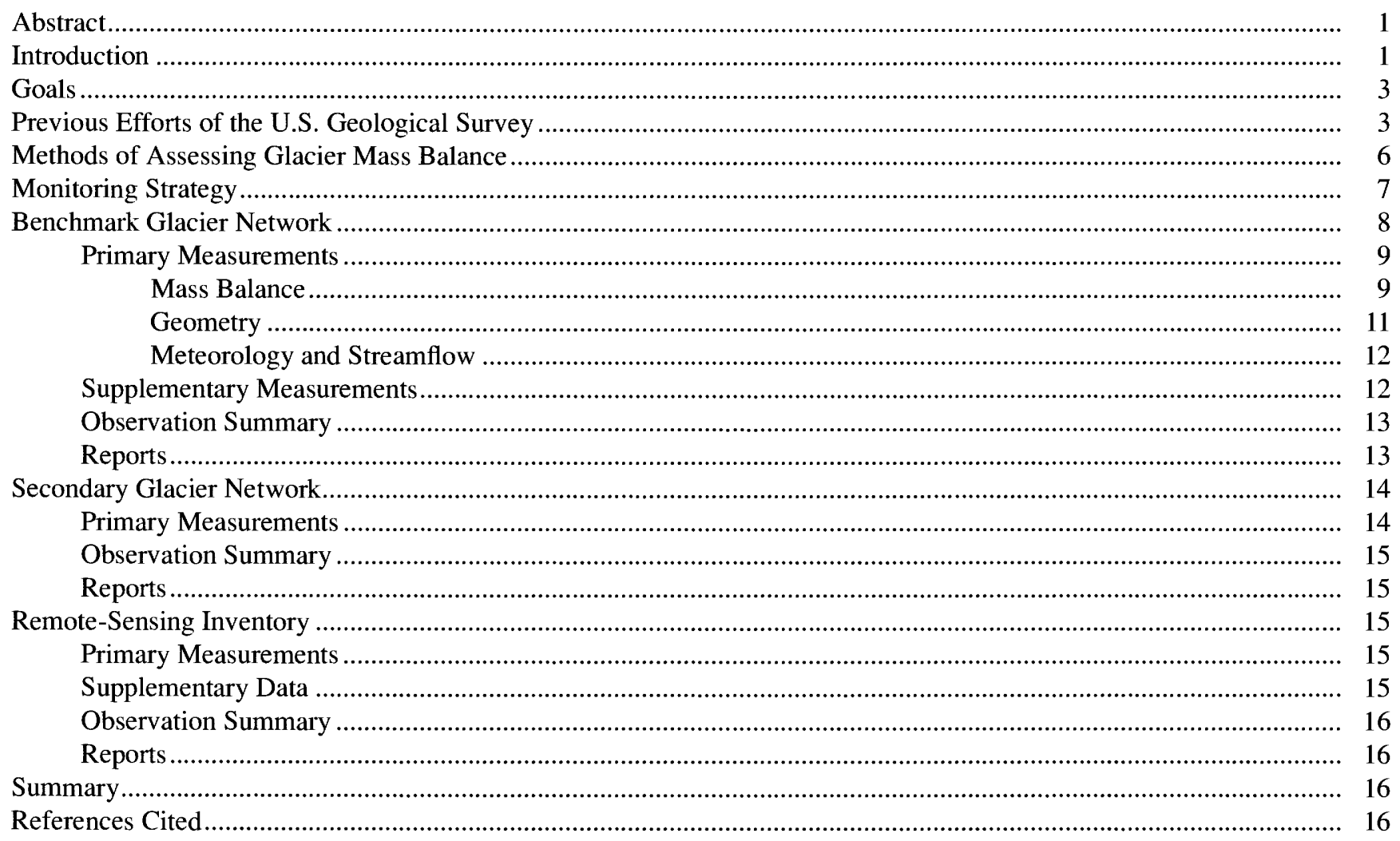

\section{FIGURES}

1-2. Graphs showing:

1. Effect of glacier cover on runoff variability .........................................................................................

2. Effect of the melting of alpine glaciers worldwide on global sea level ...................................................... 2

3. Diagram showing processes that link meteorology with glacier mass balance and their effect on landscape ........... 2

4. Map showing major glacierized regions of the United States .........................................................................

5. Diagram showing correspondence between physical processes that determine glacier change and the processes measured by the different surveillance levels...................................................................................

6. Map showing idealized monitoring strategy for a glacierized region ............................................................. 10

\section{TABLE}

1. Frequency of aerial photographic surveys for glacierized mountain regions of the United States 
CONVERSION FACTORS

\begin{tabular}{rll}
\hline Multiply & By & To obtain \\
\hline kilometer $(\mathrm{km})$ & 0.6214 & mile \\
millimeter $(\mathrm{mm})$ & 0.03937 & inch \\
square kilometer $\left(\mathrm{km}^{2}\right)$ & 0.3861 & square mile \\
\hline
\end{tabular}

Other abbreviations used in this report:

millibar (mb)

Sea level: In this report "sea level" refers to the National Geodetic Vertical Datum of 1929 (NGVD of 1929)-a geod -tic datum derived from a general adjustment of the first-order level nets of both the United States and Canada, formerly called Sea Level Datum of 1929. 


\title{
A Strategy for Monitoring Glaciers
}

\author{
By Andrew G. Fountain, Robert M. Krimmel, and Dennis C. Trabant
}

\section{Abstract}

Glaciers are important features in the hydrologic cycle and affect the volume, variability, and water quality of runoff. Assessing and predicting the effect of glaciers on water resources require a monitoring program to provide basic data for this understanding. The monitoring program of the U.S. Geological Survey employs a nested approach whereby an intensively studied glacier is surrounded by less intensively studied glaciers and those monitored solely by remote sensing. Ideally, each glacierized region of the United States would have such a network of glaciers. The intensively studied glacier provides a detailed understanding of the physical processes and their temporal changes that control the mass exchange of the glaciers in that region. The less intensively studied glaciers are used to assess the variability of such processes within the region.

\section{INTRODUCTION}

Glaciers are an important water resource of Alaska and a number of Western States because they are naturally regulated reservoirs that reduce the runoff variability by increasing flow during hot, dry periods and by storing water as ice and snow during cool, wet periods (fig. 1) (Meier and Tangborn, 1961; Meier, 1962; Krimmel and Tangborn, 1974; Fountain and Tangborn, 1985). The mass wastage of glaciers during this century has diminished the volume of water stored as ice in the natural reservoirs and has reduced the capacity of runoff from the glaciers to limit annual variations in streamflow. As demands on water resources continue to increase, the effect of glaciers on streamflow needs to be defined better. Reduction of the water in storage as glacier ice has

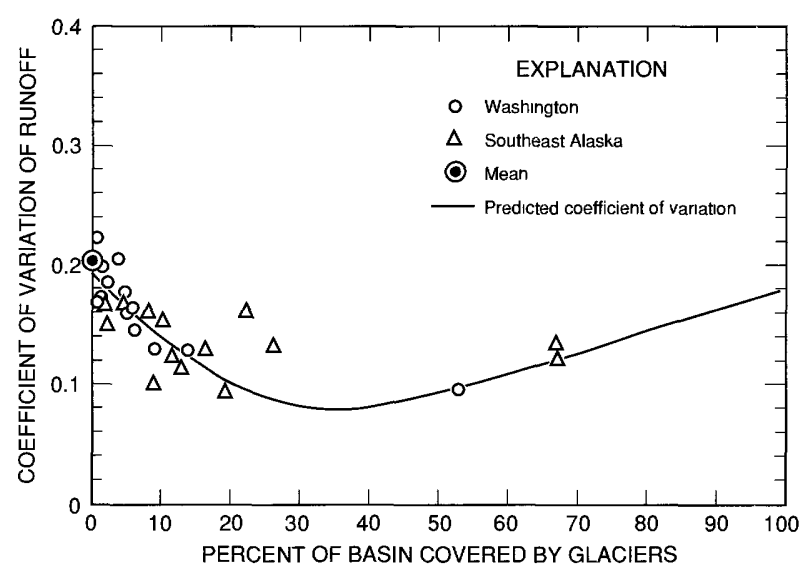

Figure 1. Effect of glacier cover on runoff variability. The coefficient of variation is the standard deviation dividec' by the mean.

contributed to the rise in global sea level (fig. 2) (Meier, 1984; Oerlemans and Fortuin, 1992). Glaciers also present special hydrologic hazards, such as floods (Post and Mayo, 1971; Driedger and Fountain, 199; Mayo, 1989; O'Connor and Costa, 1993) and debris flows (Osterkamp and others, 1986; Walder and Driedger, 1994). In addition, glaciers are recognized as sensitive indicators of climate change because their size changes in accordance with variations in mas gain or loss (Johannesson and others, 1989; Meier and Roots, 1982; Moss and Lins, 1989; Paterson, 1981). However, the relation between climate change and response of an individual glacier is only generally understood and not clearly known for large glacierized regions.

Understanding the effects of glaciers on ruroff requires a long-term program (Benson and others, 1986; Fountain and others, 1991) to define the natural variability of the processes that control glacier mass change (fig. 3). A long-term program also captures short-duration catastrophic events, such as floods and debris flows, which are difficult to predict. Furthermore, a long-term program is required to define the 


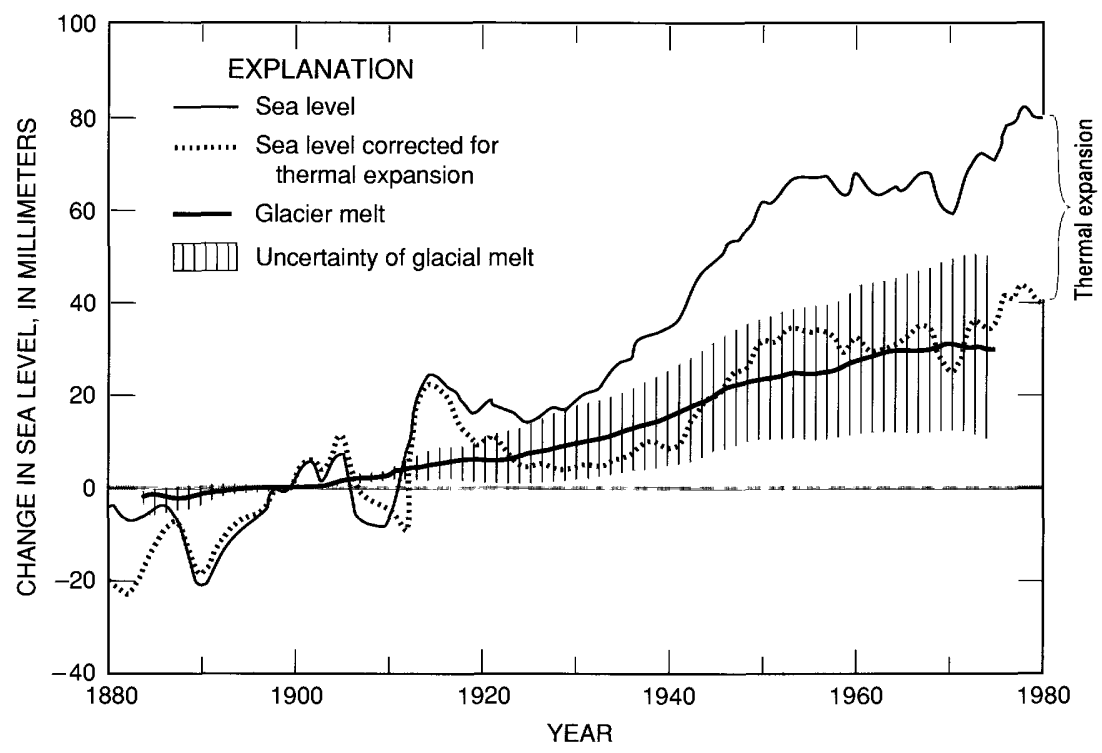

Figure 2. Effect of the melting of alpine glaciers worldwide on global sea level (from Meier, 1984).

relation between climate change and glacier response. Long-term programs are best maintained by a Federal agency because the stability in funding and personnel ensures consistency in goals and methods, thus resulting in long-term, high-quality data. The U.S. Geological Survey (USGS) has a fundamental responsibility for assessing the Nation's water resources and has internationally recognized expertise in glacier research. Together, these reasons provide the justification for the USGS to assume lead responsibility for monitoring glacier change in the United States.

The purpose of the USGS Glacier Monitoring Program is to document changes in glacier mass and extent, water runoff, and local climatic variables to increase our understanding of the relation between these variables and to evaluate the effect of glaciers on water resources and hydrologic hazards. These objectives address two mission goals of the USGS (1986):

- "Assesses water resources and develops an understanding of...natural phenomena on hydrologic systems."

- "Evaluates hazards...and develops methods for hazard prediction."

Furthermore, studies on glacier mass changes provide climatic information in remote regions, help interpret ice cores, and provide boundary conditions for modeling glacier movement.

The USGS Glacier Monitoring Program is part of a global network of observations in glacierized basins, which constitutes an international effort to assess the effects of glaciers on the global hydrologic cycle. The global network is coordinated by the World Glacier Monitoring Service, which is located in Zurich, Switzerland, and is sponsored $\mathrm{k} y$ the International Commission on Snow and Ice unter the aegis of the International Association of Hydrological Sciences. The USGS Glacier Monitoring Program has collaborated with the National Hydrology Research Institute, Environment Canada, to refine the approach to measuring glacier mass balance and to evaluate the glacier network in North America. Cir umpolar efforts with Russia and Scandinavia and cooperative

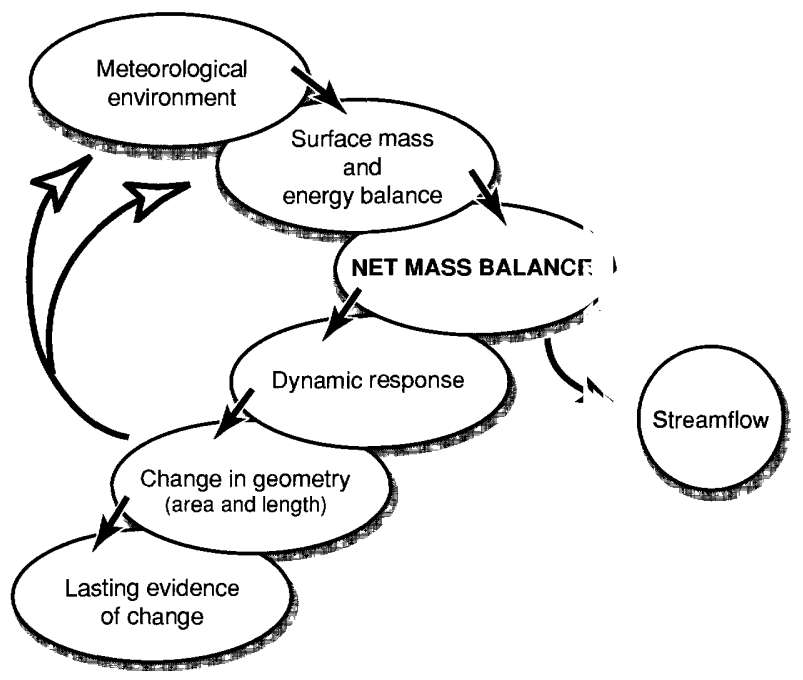

Figure 3. Processes that link meteorology with glacier mass balance and their effect on landscape (modified from Meier, 1965). 
studies southward along the Western Cordillera to the Andes Mountain Range of South America are being investigated.

This document outlines a strategy for monitoring glaciers in the United States. Three levels of surveillance are proposed. One glacier in each glacierized region is measured in detail to define the seasonal mass-balance processes, meteorological environment, and water runoff. The next level of surveillance is to measure several glaciers in each region for seasonal mass balance only. This information helps to extrapolate understanding of processes at the glacier measured in detail to other glaciers in the region. The third level of surveillance is remote sensing of glaciers by using aerial photography and satellite images to define the changing areal extent and pattern of snow and ice exposure on a large number of glaciers. The remote-sensing approach allows extrapolation to a large number of glaciers and provides a large enough sample to define the change of ice mass in a region and its effect on water resources. For each level of surveillance, the basic measurements, analysis, and reporting standards are summarized. These standards are intended neither to limit the scope of collected information nor to obstruct improvements in methodology. Rather, a consistent set of basic measurements, analytical methods, and reports is required to increase the ability to compare glacier variations areally and temporally (Fountain and others, 1991).

\section{GOALS}

This glacier monitoring strategy addresses the need to evaluate the changing water-resource and hazard potential of glaciers in the United States. The strategy is motivated by a number of fundamental research questions and supported by a comprehensive data-collection effort. The goals of the monitoring strategy are as follows:

- Quantify the magnitude of regional glacier mass change and its effect on streamflow.

- Define the relation between mass change in regional glacier cover and mesoscale weather/climate variations.

- Monitor and investigate potentially hazardous situations to develop a predictive capability.

\section{PREVIOUS EFFORTS OF THE U.S. GEOLOGICAL SURVEY}

The USGS began a program of measurements on glaciers in the late 1950's and has continued this commitment. For a comprehensive reference list of glacier studies, see Snyder (1996). The program is focused on the water-resource potential of glaciers. the relation between glaciers and climate, and glacierhazard assessment. Fundamental to each of these broad topic areas is glacier mass balance, which determines, in large part, the effect on water resources, the link between climate change and glacier response, and the potential for hazards. Because of the slow' response of glaciers to yearly changes in mass, a lingterm program was established.

Glacier mass-balance studies were in their infancy in the mid-20th century. A few glaciers were measured in Europe, and none were measured in North America. In 1958, the USGS began a study at South Cascade Glacier, Washington, to measure the mass balance directly by using surface-based metl'nds (Meier, 1958). In the mid-1960's, three more glaciers were added-Gulkana in the Alaska Range, Wolverine on the Kenai Peninsula, Alaska, and Maclure Glacier in the Sierra Nevada of California, which is no longer monitored. These glaciers (fig. 4) formed part of a north-south transect of glaciers studied for heat and mass exchange during the International Hydrological Decade (IHD, 1966-75) (UNESCO/IASH, 1970). In North America, the USGS collaborated in this effort with Canadian and American universities and governmental agencies.

During the start of the IHD, there was little agreement on mass-balance terminology and methodology. To reduce the confusion and occasional contradictions in terminology, a standardization of mass-balance terms was proposed by the USGS (Meier, 1962; Mayo and others, 1972). The methods of directly measuring mass balance at points on the glacier surface, outlined during the IHD (UNESCO/IASH, 1970), were based, in large part, on the work at South Cascade Glacier (Meier, 1962). Campbell (1969) suggested a statistical approach to determining the relation between the number of point measurements of mass balance and the resulting error in the final value of total mass balance. Fountain and Vecchia (1992) showed that, by assuming a general relation between mass balance and elevation, the error in the total mass balance can be determined, and the effect of changing the number of point measurements 

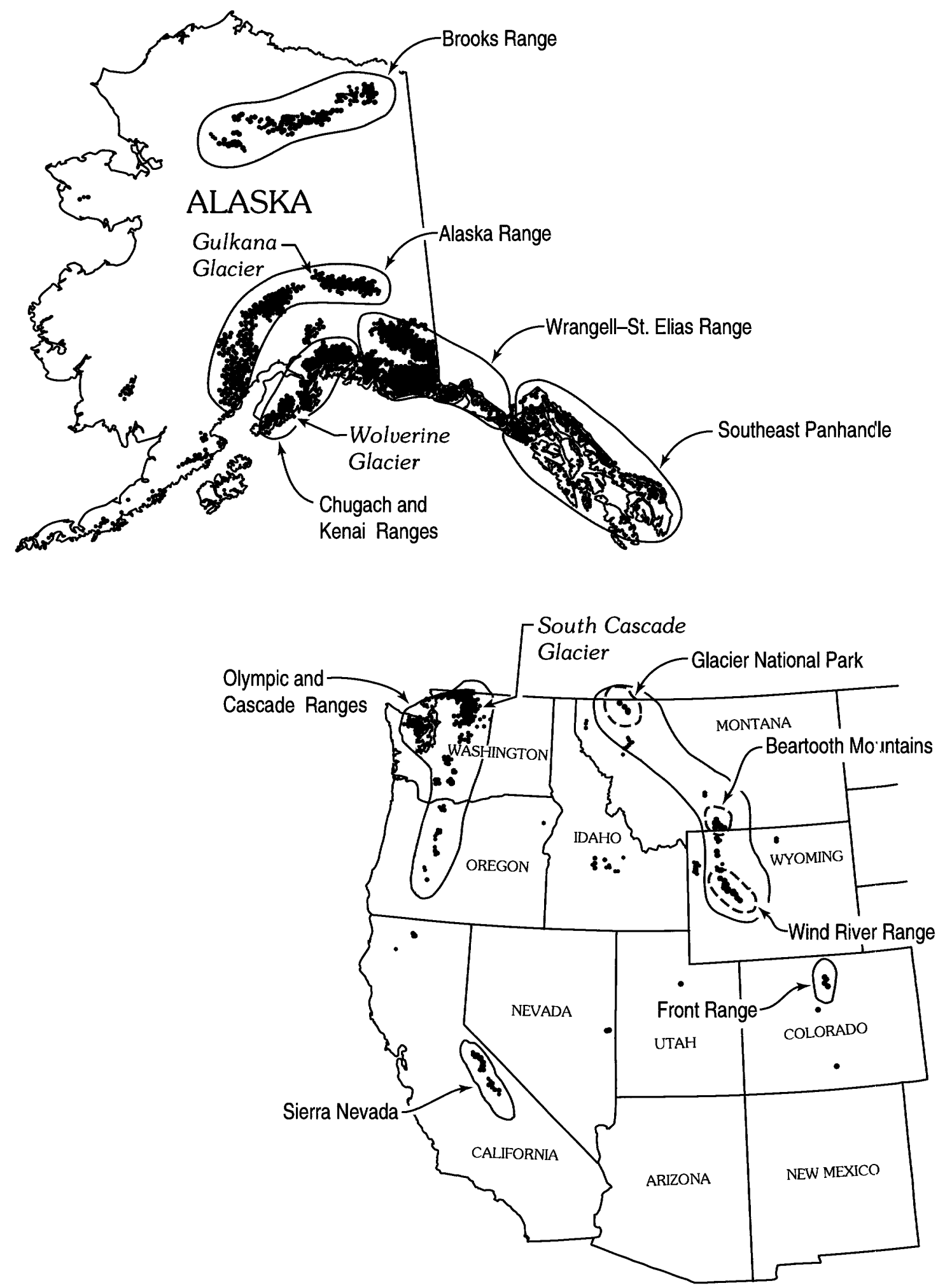

Figure 4. Major glacierized regions of the United States. The glacierized regions are shaded and enclosed by solid lines. 
can be evaluated. In addition to surface-based measurements, Trabant and Mayo (1985) concluded that subsurface measurements were required to account for an apparent mass loss from the seasonal snowpack, whereby meltwater refreezes in the firn. Furthermore, subsurface mass loss, which is caused by flowing meltwater (Mayo, 1992), may be significant in some situations.

It quickly became clear that direct measurements of mass balance, which require intensive and costly field programs, could not be used to assess the mass changes of a large glacierized region and that indirect means were required. Aerial photography provided the means to cover large regions in a short time (LaChapelle, 1962; Meier and Post, 1962). From the fraction of glacier area covered by snow at the end of the summer, the mass balance of the glaciers was inferred (Meier and Post, 1962). Glacier-surfaceelevation changes, which were derived from aerial photographs, also could be used to infer mass changes for the whole glacier, but not to determine point values of mass balance (Meier, 1966). Elevation change results from mass change and glacier movement, and to calculate point values, one also needs to know the vector of glacier movement. Meier (1966) showed contrary changes in two neighboring glaciers-North Klawatti and South Klawatti Glaciers. Tangborn and others (1990) concluded that such differences may result from differences in distribution of glacier area with elevation rather than from local complications in mesoscale climate.

Indirect methods of determining glacier mass balance also were in use during the 1960's, yet their accuracy was doubted. Tangborn and others (1975) compared three methods of assessing glacier mass balance-direct measurements on the glacier surface, estimates based on elevation changes of the glacier, and estimates from differences in the precipitation input to the glacier and stream runoff from the glacier. They found that direct surface measurements of mass changes compared well with the results of volume change based on the elevation changes of the glacier surface. Krimmel (1989) later showed that the volume change from elevation changes was an important check on the direct measurements of mass balance. Measurements of water input to the glacier (precipitation and glacier melt) greatly differed from runoff from the glacier, which indicated significant water storage in glaciers.
The use of aerial photogrammetry was furtl $\odot$.r advanced during the USGS study of Columbia Glacier, near Valdez, Alaska (Meier and others, 1 $5^{\circ} 5$ ). Because of its large area (about $1,100 \mathrm{~km}^{2}$ ), photogrammetry was utilized extensively to extend the few surface-based measurements. Rasmussen (1988) was able to infer point measurements of mass balance by applying the continuity equation to photogrammetrically determined surface velocity and elevation changes. Assuming a vertically integrated velocity in the glacier, the divergence of that velority at a point minus the surface-elevation change is equal to the mass balance at that point. This method has proved useful on the large, fast-moving tidewater glaciers of southeastern Alaska. Photogrammetric analysis of aerial (Brown and others, 1982) and ground-based (Krimmel and Rasmussen, 1986) photographs is used to determine the component of mass loss from the calving of ice from glacier termini.

By using data from the benchmark glacier network, which included Gulkana, Wolverine, and South Cascade Glaciers, the USGS has been able to examine the link between climate change and glacier response and the effect of glaciers on water resources. The conceptual linkage between climate, as it affects glacier mass balance and glacier change, was illustrated by Meier (1965) (modified in fig. 3). On the basis of analysis of aerial photography, Meier and Post (1962) were able to quantify regional variations and to report that the advance/retreat activity of glaciers in Washington State was not in phase with glaciers in Alaska. Walters and Meier (1989) examined the mass-balance data, which were derived from the USGS glacier and the Canadian networks, in relation to climate variability. They confirmed the out-of-phase relation between glaciers in Alaska and those in southern British Columbia and Washington and demonstrated the effect of the Aleutian low-pressure system in steering storm tracks toward either Alaska or Washington. McCabe and Fountain (1995) documented changes in the $700 \mathrm{mb}$ circulation pattern and the decreased mass balance at South Cascade Glacier in Washington and the increased mass balance of Wolverine Glacier in south-central Alaska. Mayo and Trabant (1984) demonstrated that the mass of some glaciers in southern Alaska increases rather than decreases with rising winter air temperature. The temperature increase is associated with moisture-bearing storms from the Pacific Ocean. 
Investigation of the effect of changes in glacier mass on water resources has been a continuous effort by the USGS. The distinctive characteristics of runoff from glaciers were explained by Meier and Tangborn (1961). The causes for these characteristics were explored by Meier (1969), Tangborn and others (1975), and Fountain (1992). Glaciers also have a buffering effect on streamflow that attenuates variations in runoff (Meier, 1969; Krimmel and Tangborn, 1974). Further investigations by Fountain and Tangborn (1985) explained the delay of seasonal peak flow through the summer and presented a theoretical prediction of the attenuation for basins with different fractions of glacier cover (fig. 1). A number of studies have examined the physical processes of water flow in a glacier to understand how they control the discharge of water from a glacier. These studies include examination of surface processes that affect the rate of water input to the glacier's interior (Fountain, 1989, 1994) and the processes that control the rate of movement through and under the glacier (Krimmel and others, 1973; Hodge, 1976, 1979; Fountain, 1992, 1993, 1994).

The mass wastage of glaciers contributes flow to streams and rivers that would otherwise not be present if the glaciers did not exist or were in equilibrium. Tangborn (1980) showed that the mass loss from glaciers in the Columbia River Basin supplied $\$ 18$ million in generated electricity. The effect of glacier mass balance is not limited to local glacierized basins. The mass wastage of alpine glaciers worldwide has contributed a significant fraction to sea-level rise in the past century (fig. 2) (Meier, 1984).

There are thousands of glaciers in the United States for which no mass-balance data or other surface-based information are available. The USGS has been documenting the condition of many of these glaciers by aerial photography. This effort has cataloged a collection of more than 50,000 negatives of glaciers of western North America, with a few glaciers represented nearly every year since 1960 . This record makes available a history of transient snowlines and terminus positions in areas where no glacier balance data exist. As previously mentioned, transient snow-lines may be used to estimate glacier mass balance (Meier and Post, 1962), and terminus changes commonly can be related to long-term climate change. Observation of a large number of glaciers also has resulted in the understanding that certain types of glaciers, such as surging (Meier and Post,
1969) and tidewater (Post, 1975), respond strongly to nonclimatic factors.

\section{METHODS OF ASSESSING GLACIER MASS BALANCE}

The observations needed to determine glacier mass balance depend on the processes that control the mass exchange, the information desirec about the mass change and, consequently, the approach to assessing that change. This section briefly summarizes the different mass-balance-assessment methods. Later sections describe the application of these methods to different levels of surveillance.

The concept behind measuring glacier mass balance is quite simple-sum the mass losses and gains; however, in practice, it becomes complex. Generally, the main source of mass inp it is snow accumulation from snowfall and avalanches. Other sources include the freezing of rain within the snow, condensation of water vapor, and rockfall events. Processes of ablation (all forms of mass loss) include melting from the surface and interior of the glacier, evaporation, and calving of ice from the glacier margin. Another consideration is the redistribution of mass, such as the refreezing of surface meltwater in the cold layers below the snow surface.

Methods of determining glacier nass balance include direct measurements of mass crange (UNESCO/IASH, 1970; Meier and others, 1971; Paterson, 1981; Østrem and Brugman, 1991), calculation of flux divergence based on glacier velocity and surface height change (Rasmussen, 1988), and calculation of volume change based on elevation changes of the glacier surface (Mayo and others, 1985; Haakensen, 1986; Mayo and Trabant, 1986; Krimmel, 1989). Mass change also can be inferred from the elevation of the snowline or the ratio of snow-covered area to the total area of the glacier at the end of the summer (Meier and Post, 1962). The hydrologic method, which is based on a comparison of precipitation and runoff, does not provide results consistent with the other methods (Tangborn and others, 1975) and is considered to be inadequate as a technique for estimating mass balance (Fountain and others, 1991).

Direct measurement of glacier mass-balance components provide the most-detailed information about the processes that control mass balance, spatial differences, and changes during time. The specific mass balance (mass per unit area) is calculated from 
surface-based measurements of glacier-surface height changes and the density of the surface layers of ice or snow. By using the area-elevation distribution of the glacier surface, point measurements of mass balance are extrapolated to all parts of the glacier to determine total mass change. In addition, the amounts of water refrozen in the firn (Trabant and Mayo, 1985) and melted in the body of the ice (Mayo, 1992) are calculated. Measurements of ablation owing to calving are not made directly because the calving face is unstable. Instead, calving losses are calculated from photographs (Brown and others, 1982; Krimmel and Rasmussen, 1986).

Flux divergence measurements rely on the continuity equation to infer mass balance (Rasmussen, 1988). The loss or gain of mass at a point is calculated from the divergence of the glacier velocity, which is integrated over the thickness of the glacier and the surface height change. This technique has been applied to points derived from photogrammetric analysis of surface velocity and surface height.

Although this method may not be as accurate as direct measurements because of the necessary assumptions and accuracy of the photogrammetry, it may be the only method applicable on very crevassed surfaces or where logistic costs are prohibitive. The mass balance can be inferred anywhere on the glacier where surface targets can be repeatedly identified. The time-resolution of this method is limited by the interval between photographs, which can be no shorter than the time required to displace surface targets a distance greater than the error in the photogrammetric analysis.

To determine mass balance from volume change, an assumption is made about the density of the glacier, and the density is multiplied by the integrated surface height change over the glacier area (Haakensen, 1986; Krimmel, 1989). This method is very useful for determining the total mass balance of a glacier over long periods of time. The surface-height change may be determined from either surface-based measurements of glacier elevation or photogrammetrically determined elevations. This method cannot be used to determine spatial variations of mass balance on the glacier, such as elevation gradient, because a component of the glacier velocity is normal to the glacier surface, and although the surface elevation has not changed, a significant mass flux may have passed through that surface (Meier, 1966). This method is useful for determining mass balance in regions of difficult terrain or on extremely large glaciers or ice sheets. Furthermore, it is quite useful for checking surface-based measurements of mass balance (Haakensen, 1986; Krimmel, 1989; Fountain and others, 1991). The average mass-balance change with elevation can be determined if the total mass change of two glaciers is known and the same mass-balance/ elevation relation is assumed for both glaciers (Tangborn and others, 1990).

The yearly mass balance of a glacier is linked to the elevation of the equilibrium line (dividing line between areas of net mass gain and loss), which is approximated by the snowline at the end of the summer, and to the accumulation-area ratio (fraction of the glacier area covered by snow) (Meier and Post, 1962). Although the quantitative accuracy of this method is limited, it provides a means of rapidly assessing net gain or loss of glacier mass in a region by means of remote sensing.

\section{MONITORING STRATEGY}

To document the processes that link glacier changes to climate and to predict the long-term effect of glacier mass change on streamflow, detailed measurements are required. Because of the vast number of glaciers and their wide distribution, we also need to sample a large number of glaciers to define variations within and between regions. However, it is not feasible to acquire detailed measurements on a large number of glaciers; instead, a small number of glaciers will be monitored at different levels of intensity.

The glaciers of the United States can be divided into nine major regional groups (fig. 4). This div: sion is based on a qualitative understanding of the relation between weather patterns, local climate, and the glaciers. Mass-balance variations in one region probably cannot be used to predict those in anothar region. Within each glacierized region, the glaciers will be monitored by using a nested approach that consists of three hierarchical levels of documentation. This approach is philosophically similar to that proposed for monitoring sediment in streams and rivers (Osterkamp and Parker, 1991). One intensively studied glacier, called a Benchmark Glacier, will be located in each glacierized region. Secondary glariers will be chosen throughout the region to define spatial trends and variability in mass balance, but will not be studied as intensively as the Benchmark Glaciers. Additional glaciers in the region will be monitored by 
using only remote sensing. Knowledge of the physical processes that control mass exchange on the intensively studied Benchmark Glaciers will be used to understand the mass changes on the less intensively studied glaciers. In turn, changes in the less intensively studied glaciers will provide information on the range of glacier variation within the region. The attributes of each group of glaciers are briefly summarized.

The Benchmark Glacier Network will consist of one glacier in each glacierized region on which detailed direct measurements of seasonal glacier mass changes, meteorological environment, and streamflow variations are collected. These data will be used to examine the processes and develop the models that link meteorological changes to glacier mass and streamflow variation within each glacierized region. Because the cycle of mass change is annual and climatic cycles, such as El Niño-Southern Oscillation events, have larger periods, long-term data bases that span decades are required. Because of the expense of maintaining each site, the number of sites will be restricted to one Benchmark Glacier in each glacierized region. The information gained from the Benchmark Glacier Network is fundamental to understanding the cause of glacier change and impact on water resources. For this reason, the Benchmark Glacier Network shares the philosophy of the USGS National Hydrologic Benchmark Network (Cobb and Biesecker, 1971): "Data will be collected indefinitely...will provide valuable information on time trends..." and will be "used to study cause-and-effect relationships between various physiographic, meteorologic, and hydrologic variables." One Benchmark Glacier in each glacierized region is considered to be adequate to define the salient physical processes that govern glacier evolution and streamflow in that region.

The Secondary Glacier Network comprises three to five glaciers in each glacierized region where yearly (as opposed to seasonal) measurements of glacier mass balance will be made. No other direct measurements are intended for this network. Based on the processes elucidated at the Benchmark Glaciers, yearly mass-balance data collected from these glaciers will aid in adapting mass-balance models to the range of glacial conditions in the region.

The Remote-Sensing Inventory, which includes aerial photographic surveys and satellite images, provides a fast, inexpensive survey of glacier change in a region. Glacier characteristics that can be monitored remotely include area, terminus and snowline position, accumulation-area ratio, and surface elevation, as well as glacier events, such as surging (sudden accelerations) or the filling or draining of ice-dammed lakes. This information, particularly accumulation-area ratio, can be used to infer mass balance and, thereby, extend and test massbalance modeling. From the large number of glaciers monitored by remote methods, spatial t"ends will be documented, and degree of variation will be quantified. Benchmark and secondary glaciers will be included in the Remote-Sensing Inventory because they provide the ground-based information needed to interpret the images. The number of glaciers monitored solely by remote sensing will depend on the size of the region and number of glaciers; however, 20 to 40 glaciers are desirable.

These three levels of documentation are mutually supporting and satisfy the simultaneous need for detailed studies and broad coverages in a costeffective manner. A summary of surveillance levels and physical processes measured is depicted in figure 5, and an idealized implementation is depicted in figure 6. This strategy outlines the purpose and scope of the USGS Glacier Monitoring Program and provides a framework to cooperate efficiently with other agencies and institutions.

\section{BENCHMARK GLACIER NETWORK}

The Benchmark Glacier Network is a set of intensively studied glaciers, one in each glacierized mountain region of the United States. The purpose of this network is to collect and provide data needed to understand the effects of climate on glacier mass changes and the resulting effect on streamflow. These glaciers are index sites for the surrounding glacierized region, whereby the understanding gain $\mathrm{d}$ from these sites will be used to predict how the glaniers in the region respond to climate and affect streamflow. This understanding depends, in part, on information gained from the Secondary Glacier Network and the RemoteSensing Inventory

A number of important factors, which parallel those of the IHD (UNESCO/IASH, 1970), need to be considered in the selection of a Benchmark Glacier. The drainage basin should be well defined hydrologically, and the gaged portion should be at least 30-percent glacier covered. Topographic characteristics (area, orientation, and elevation range) and mode 


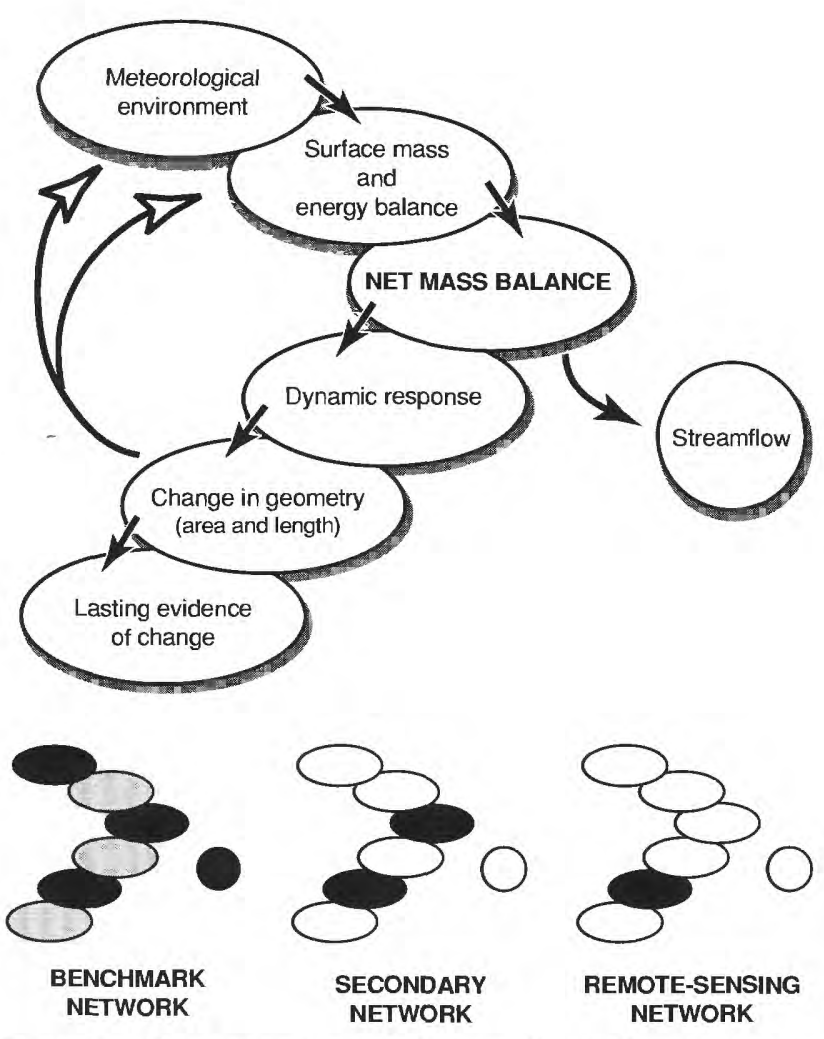

Figure 5. Correspondence between physical processes that determine glacier change and the processes measured by the different surveillance levels. The main processes are shown in the large figure. The processes monitored at each surveillance level are indicated at the bottom by shading the corresponding ellipse. Light shading indicates detailed surface mass-balance measurements and occasional energy-balance measurements.

of snow accumulation should be typical of the glaciers in the region. Access to the glacier should be simple to reduce transportation costs, and most of the glacier surface should be accessible to facilitate data gathering. However, the glacier should be sufficiently remote to reduce possible tampering with instruments and installations. Prior information about the glacier, such as its advance and retreat activity, its mass balance, and its meteorological environment, also is beneficial. Currently (1996), three glaciers compose the USGS Benchmark Glacier Network-Gulkana in the Alaska Range, Wolverine in the Kenai Mountains, Alaska, and South Cascade in the North Cascade Range, Washington (fig. 4).

Repeated, systematic measurements of Benchmark Glaciers are the primary method for determining how glaciers respond to climatic variations and affect water resources. Measurements are divided into two categories. Primary measurements are considered to be fundamental and are required, if possible, for every Benchmark Glacier. Secondary measurements are considered to be important and significantly enhance the usefulness of the monitoring program, but are not considered critical to assessing mass change.

\section{Primary Measurements}

\section{Mass Balance}

Documenting glacier mass changes is fundamental to understanding the response of glaciers to changes in climate and the effect of glaciers on water resources. For these reasons, mass balance is one of the primary measurements of the Benchmark Glacier Network. Mass balance is measured directly through detailed surface-based measurements to gain an understanding of how the processes that control mass balance vary across the glacier and through time. These data will be used to develop and test models that predict glacier mass balance and glacier-derived streamflow.

The mass balance is evaluated by measuring the addition and loss of snow and ice mass at points on the glacier surface and extrapolating the point data to the whole glacier surface (UNESCO/IASH, 1970; Meier and others, 1971). The gain or loss of mass within the glacier, which is caused by freezing of water (Trabant and Mayo, 1985) or melting of ice (Röthlisberger, 1972; Mayo, 1992), can be estimated. The quantities of ice melt commonly are small compared with the exchange of mass at the surface. At this time, there is no standard procedure that governs the number of measurement points of snow and ice accumulation and ablation on a glacier, but the rule-of-thumb approach is to make enough point measurements of mass balance to sample adequately the range of variation on the glacier. The number of points may be reduced once the spatial pattern of mass balance has been determined.

For a calving glacier, the mass loss from calving may be significant and can be evaluated by using photography (Brown and others, 1982; Meier and others, 1985). To evaluate mass balance of a calving glacier properly, in addition to quantifying the mass balance of the surface of the glacier, changes in terminus position and velocity of ice flow to the terminus also must be measured to determine the rate of calving.

The important mass-balance values are seasonal and yearly balances and the balance change with 


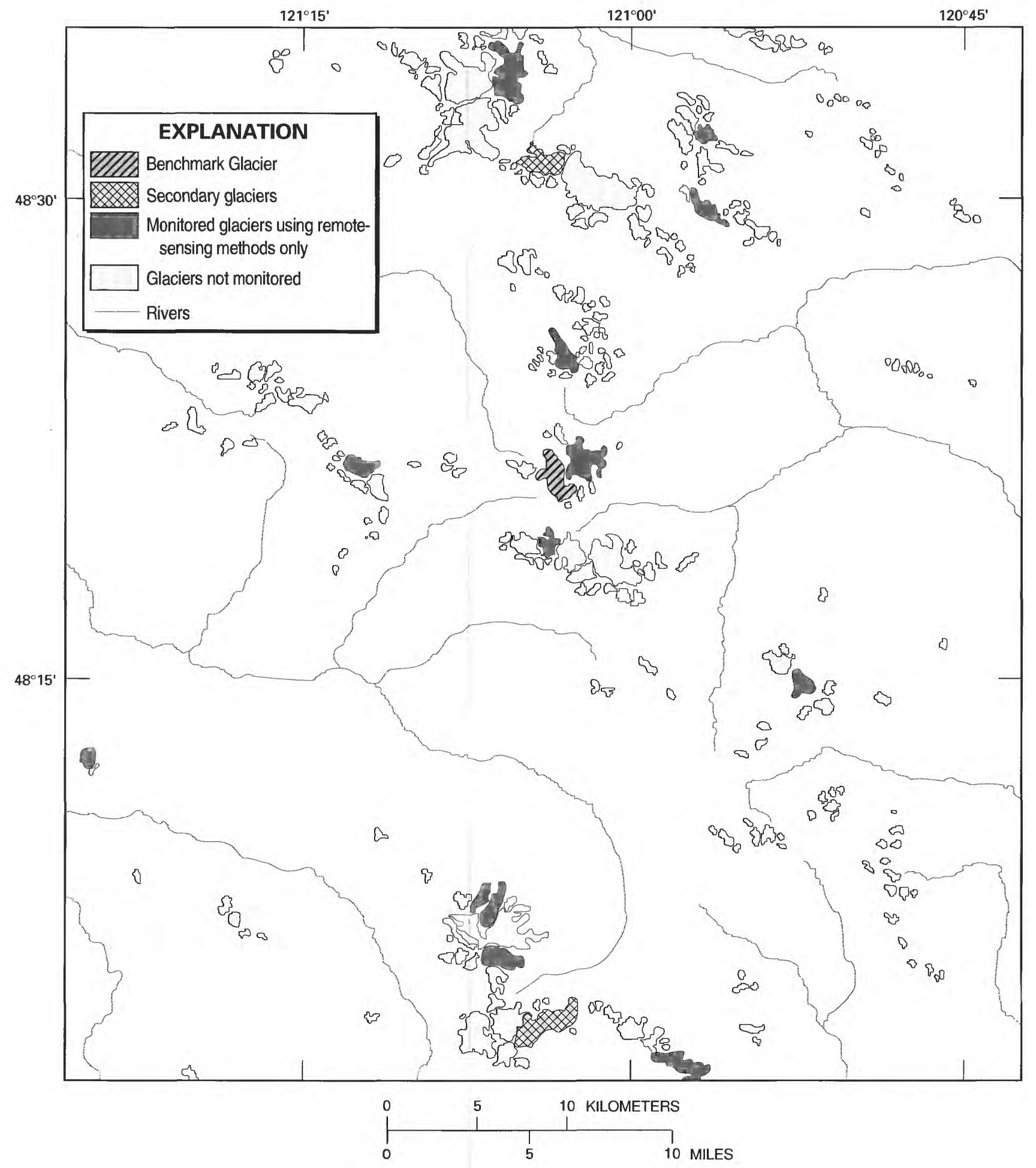

Figure 6. Idealized monitoring strategy for a glacierized region. 
elevation. Seasonal balance measurements are defined during periods when the glacier is dominated by accumulation or ablation processes (Paterson, 1981) The length of each season varies among glacierized regions and from year to year. For glaciers with large elevation ranges, winter conditions of snow accumulation may prevail at high elevations, while summer conditions of icemelt and snowmelt prevail at lower elevations. In these situations, the net mass balance of the whole glacier determines the division between summer and winter. Seasonal balances are important because yearly balance alone does not indicate the magnitude of accumulation or ablation. From a climatic perspective, the weather in one season is not necessarily correlated with the next; a winter of large snow accumulation does not portend a summer of cool, rainy weather (Walters and Meier, 1989). Modeling the effect of climate on glaciers depends, in part, on correctly predicting seasonal influences.

A yearly value of mass balance needs to be calculated because it is the link between the weather influences on the glacier, the resulting change of glacier geometry, and the effect on landscape as illustrated in figure 3. Mass balance is reported as an annual value determined between fixed calendar dates or as a net change between successive minimums in mass balance (Mayo and others, 1972). To exploit the advantages of both approaches, the USGS has adopted a combined system of measurements (Meier and others, 1971; Mayo and others, 1972); both values are calculated and reported. Because glacier mass balance is calculated from the extrapolation of point measurements, which are subject to errors, the mass balance should be periodically compared with changes in ice volume (Krimmel, 1989).

The change in mass balance with elevation is an important relation because, in addition to the distribution of glacier area with elevation, it determines if a glacier is in equilibrium or whether continued advance or retreat may occur. This relation provides a physical basis for mass-balance modeling and has been used to explain the mass exchange during previous glaciations (Pierce, 1979; Porter and others, 1983). Changes in the mass balance/elevation gradient from year to year indicate the effect of weather variations, and gradient differences among glaciers reflect influences of the climatic environment and topographic characteristics.

The annual equilibrium line is the demarcation between the accumulation and the ablation zones at the end of the summer melt season (UNESCO/IASH,
1970). The position of the annual equilibrium lire relative to the distribution of glacier area indicates whether the glacier has gained or lost mass. The elevation of the annual equilibrium line determined from aerial photography or satellite images can b? used to assess quickly whether the glaciers of a region are gaining or losing mass (LaChapelle, 1962; Meier and Post, 1962). Also, former mean elevations of the equilibrium lines can be estimated from the geologic record, thus providing information about glacier characteristics long before current glaciological observations were made (Porter, 1977; Waythomas, 1990).

The position of the annual equilibrium line will be determined every year and plotted on a map of the glacier. Determination of the position of the annual equilibrium line can be made by the following methods: sketching the position on a map, surveying, a time-lapse camera, aerial photographs, or satellite images (Williams and others, 1991); however, these techniques require almost daily observations near the end of the ablation season. Therefore, the position is usually inferred retroactively from mass-balance and meteorological data.

Another measure, which is closely related to the equilibrium line, is the accumulation-area ratio, the fraction of accumulation-area ratio to total glacier area (Meier and Post, 1962). The ratio is important because it can be easily determined from aerial photographs and is one measure that can be used to relate the Remote-Sensing Inventory to the Benchmark and Secondary Glacier Networks.

\section{Geometry}

The geometry of a glacier is constantly changing in response to mass changes and glacier movement and is an important link between dynamics and mass change. Furthermore, changes in geometry, specifically area, terminus position, and surface elevation, are important for evaluating the effect of glaciers on water resources and landscape and to verify surface mass-balance measurements. The fraction of the basin covered by a glacier directly affects the runoff variation from the basin (Krimmel and Tangborn, 1974; Fountain and Tangborn, 1985; Braithwaite and Olsen, 1988). Changes in glacier area largely result from changes in terminus position. The terminus position also defines glacier length, which is one of the variables used to evaluate the effect of climate change (Huybrechts and others, 1989; 
Johannesson and others, 1989). Furthermore, terminus position can be reconstructed from the geologic record and used to infer past climate (Porter, 1977; Meierding, 1982; Rodbell, 1992). Therefore, terminus position should be monitored and mapped near the end of the ablation season by either photogrammetry or geodetic surveying methods if appreciable change has occurred. It is proposed that a Benchmark Glacier be remapped when the glacier length changes by 0.5 percent since the last mapped position.

The surface elevation of a study glacier should be mapped to document changes in the elevation distribution of glacier area and for determining volume change. The distribution of area with elevation is an important relation that determines, in addition to the mass balance/elevation gradient, whether the glacier is in climatic equilibrium (Furbish and Andrews, 1984; Tangborn and others, 1990). The glacier volume change, which is derived from changes in surface elevation, provides an important and independent check on mass-balance measurements (Haakensen, 1986; Krimmel, 1989). Mapping intervals depend on the rate of change, which may vary widely. For example, a calving tidewater glacier in catastrophic retreat may require mapping every 2 years; conversely, for slowly changing glaciers, such as polar glaciers, the mapping interval may be 15 to 20 years or more. In the absence of information about surface-elevation changes, mapping intervals should not exceed 10 years. Topographic maps can be derived from photogrammetry, with independent geodetic information to provide an estimate of accuracy, or by geodetic methods alone. If funding precludes mapping at necessary intervals, then mapping-quality aerial photographs should be acquired and stored until maps can be constructed. If mapping-quality aerial photographs cannot be obtained, then surface elevations should be measured during the interval between aerial photoflights by measuring the elevation of the glacier surface at index sites located at fixed $x-y$ locations.

\section{Meteorology and Streamflow}

The meteorological environment of the Benchmark Glacier will be monitored to examine the links between climate, glacier response, and streamflow. The variables to be measured are precipitation, air temperature, humidity, windspeed and direction, solar radiation, and stream stage. The meteorological instruments are best located at the elevation of the long-term equilibrium line. Stream discharge will be measured because it defines the hydrologic effects of glaciers on the watershed. Precipitation, particularly snowfall, is difficult to measure accurately in windy, mountainous environments. Furthermore, snow is redistributed in alpine basins by wind and avalanching. Precipitation-gage catch may be improved by using a windshield, such as a Nipher Shield (Goodison and Metcalfe, 1992). The efficiency of this type of shield is a function of wind speed, such that knowing the wind speed, the measured catch can be adjusted to the true precipitation value (Goodison and Metcalfe, 1992). This factor is imfortant in the windy environments common to glaciers. The storage precipitation gage should be charged with an antifreeze solution so that new snow melts on contact with the fluid. A sonic transducer, located near the gage, may be used to determine when now snow is falling and help approximate the precipitation during times when the orifice of the gage is clc gged. Air temperature and humidity sensors must be shielded from radiation and ventilated to reduce the effect of solar heating. Standard USGS practices for measuring stream stage, making discharge measurements, and developing a stage/discharge rating curve will be employed.

The meteorological and streamstage measurements should be recorded at intervals of no longer than 1 hour. These data should be telemetered, in part, to determine whether the data-collection system is working. Generally, the sites are remote, and access incurs a significant travel expense. Telemetered data indicate when the sites need repair and reduce the magnitude of missing records and the cost of unnecessary field visits.

\section{Supplementary Measurements}

Although not vital for assessing rass balance and changes in glacier geometry, several additional observations are extremely useful. Glacier-bed topography, which is a one time measurement, is important for determining absolute volume changes from the relative volume change calculated from surface elevations. It also is a significant parameter for predicting glacier movement, estimating the hydraulics of basal water flow, and modeling glacier dynamics. Bed topography can be determined by using ice radar (Watts and Wright, 1981; Bogorodsky and others, 1985). 
Another observation is the rate of ice movement, which links mass balance with glacier geometry. Ice movement is detected by repeated surveying of targets on the glacier (Meier and Tangborn, 1965; Paterson, 1981) or by photogrammetric analysis of natural (crevasses) or artificial targets on a glacier (Meier and others, 1985). For a long-term program, where the mass and volume of a glacier are expected to change, a coincident data set of flow information is useful for determining the dynamic response of glaciers to changes in mass input.

Water-quality measurements, which include sediment transport and electrical conductivity, are indicative of glacial erosion and subglacial water processes (Fountain, 1992). The measurements are recorded at intervals no longer than 1 hour and telemetered, if possible. Hourly measurements are important to record the diurnal variation in water quality. Telemetered data are a practical consideration for these remote field sites to help determine the schedule of visits to maintain the measurement equipment and reduce gaps in the data record.

\section{Observation Summary}

The observations and calculations associated with glaciers in the Benchmark Network are summarized as follows:

Mass balance

- Point measurements/calculations of mass balance on the glacier

- Seasonal mass balance, summer and winter

- Net and annual mass balance

- Mass balance as a function of elevation

- Equilibrium-line elevation

- Accumulation-area ratio

Geometry

- Glacier area

- Terminus position

- Surface elevation

Meteorology and streamflow

- Precipitation

- Air temperature and humidity

- Wind speed and direction

- Solar radiation
- Stream discharge

Supplementary data

- Glacier-bed topography

- Glacier velocity

- Water-quality data—suspended sediment, electrical conductivity

\section{Reports}

All the glaciological, meteorological, and streamflow data that are part of the Benchmark Glacier Program and the data that are used to calculate the mass-balance quantities, will be published annually in the report series of the U.S. Geological Survey. The data also will be archived on magnetic or optical media to facilitate computer access and be submitted to the World Data Center for Glaciology, University of Colorado, Boulder, Colo. Results of the mass-balance data will be made available to the World Glacier Monitoring Service to continue the international cooperation in glacier observations.

A brief narrative summary of field activities at the glacier for the year will be written. The narrative should include the number of visits and accomplishments during each visit, particularly instrument repairs or location change. Special events, such as outburst floods or other uncommon events, will be noted.

The location of the data-collection sites will be indicated on a base map. All data collected by digital or analog recorders will be reported in tables, plotted as daily averages, and archived in a digital data base in the original time base. Exceptions are solar-radiation, precipitation, and stream sediment and discharge data, which will be presented in tables and plots as daily sums rather than averages. Summary statistics, which include monthly averages and totals, will be included in the tables. If possible, plots of the data in the original time base will be included to illustrate the details of diurnal variations. The data will be archived in the original and daily time intervals on magnetic or optical media

The positions of point measurements of mass balance will be plotted on a map of the glacier. The data from each position will be listed in tables and will include the position $(\mathrm{x}, \mathrm{y}, \mathrm{z})$; dates of measurements; and all data, either measured or inferred, used to calculate the mass balance at that point. Mass balance will be expressed in water-equivalent terms. Relevant plots (for example, snow density with depth, stake 
movement) also will be included. The position change of stakes used to calculate glacier flow velocity will include the $x, y, z$ positions of the stake for every measurement, as well as the calculated magnitude of the horizontal and vertical components of velocity.

The elevation of the equilibrium line will be indicated and if the position across the glacier is known, then it should be plotted on a map. If the position was inferred, then the method of inference should be included. If the terminus position and surface elevations are measured, then the results and changes from the previous measurements also will be included.

The method of calculating mass balance will be presented with the assumptions explained and the fundamental equations included. Annual, net, winter, and summer mass balances will be reported. In addition, the mass-balance values, glacier area, and area-integrated mass-balance values will be plotted as a function of elevation and summarized in a table.

If a method used in a continuing program is changed, then the new method will first be verified and reviewed by USGS colleagues in the context of a USGS report or in a peer-reviewed journal. One example of this process is the paper by Mayo (1972), which described a self-mixing antifreeze solution for recording precipitation gages. All methods also will be reviewed annually, in the context of annual reports from each site, to maintain quality and to seek improvements continually.

\section{SECONDARY GLACIER NETWORK}

The Secondary Glacier Network will comprise glaciers that are monitored with a reduced set of measurements compared with the Benchmark Glacier Network. These glaciers provide information on the variability of glacier mass balance across a region, in contrast to detailed measurements of mass balance, runoff, and meteorological environment at a single glacier. Documenting the variation of mass balance across a region is essential for the development of models of regional glacier variation and their effect on runoff. Variations may be caused by differences in local climate and topography. Glaciers in the Secondary Network will be candidates for benchmark status in regions where the initially selected Benchmark Glacier may have to be abandoned because of changes implemented by the landmanagement agency. This arrangement provides for a number of different glaciers to be monitored at a low cost and provides important background information for potential inclusion in the Benchmark Glacier Network.

Although maintaining data collection at secondary glaciers indefinitely is desirable, it is more practical to consider these glaciers a flexible part of the monitoring program. For example, if two secondary glaciers exhibit mass-balance variations that are virtually identical or are similar to the Benchmark Glacier, then observations on one of the glaciers could be discontinued. Also, th $\bullet$ Secondary Glacier Network provides opportunities for cooperation with other agencies, such as the National Park Service, or university research programs, that may wish to develop glacier-monitoring programs without requiring a comprehensive program of measurements, such as that of the Benchmark Glacier I'etwork.

\section{Primary Measurements}

At minimum, annual or net mass lalance will be calculated for each secondary glacier. Although surface-based measurements are desiral $1 \mathrm{le}$ because of the detail provided, alternative methods to determine mass balance, such as flux-divergence or volume methods, are appropriate. A combination of methods also may be used. In addition, the elevition of the equilibrium line and the accumulation-area ratio need to be measured. These data will be compared with the mass-balance values from the Benchmark Glacier to define the trends within each glacierized region better. Furthermore, the accumulation-area ratio will be compared with those ratios determined from the Remote-Sensing Inventory to infer more precisely mass changes for the region.

The glacier area and, hence, terminus position must be known to estimate a glacier's mass balance. This information will be compared with the mass and the glacier-area changes obtained from the RemoteSensing Inventory.

Several additional calculations are recommended and include seasonal mass balance, mass-balance change with elevation, and surface elevation. Each of these calculations significantly increases the understanding of the geographic variability of the processes that control glacier mass balance. Other data outlined in the Ben hmark Glacier Network, such as subglacial topography, meteorology, and water runoff, also would be useful to 
expand understanding of the regional variability in these variables. This knowledge would improve the ability to predict regional mass-balance variations and effect on runoff.

\section{Observation Summary}

Mass Balance

- Net mass balance

- Equilibrium-line elevation

- Accumulation-area ratio

Geometry

- Glacier area

- Terminus position

Supplementary data

- Seasonal mass balance

- Mass balance with elevation

- Surface elevation

\section{Reports}

Annual reporting of the Secondary Glacier Network data should maintain the standards set for the Benchmark Glacier Network. For example, the method used to estimate mass balance should be described with all the fundamental measurements included in tables and graphs.

\section{REMOTE-SENSING INVENTORY}

Aerial photographs and satellite images of glacierized regions provide the most efficient means for monitoring regional glacier activity. For practical reasons, such as time and available resources, few glaciers can be observed on the ground, whereas hundreds can be observed from aircraft and thousands from satellites. Remote imaging provides direct information on changes in glacier area, terminus position, snowline location, and accumulation-area ratio. Furthermore, remote images document unusual activity, such as surging, or development of potential hazards, such as ice-dammed lakes. Such imagery enables the extension of ground observations, which typically are limited to a few basins, to broad regions. When properly annotated and stored, photographic or digital images are the most complete record of glacier conditions available. Although aerial photographs are specifically discussed because of long experience with their use, the resolution of satellite images is improving, and advances in interpretation of these images have brought the technology ever closer tc the utility of aerial photographs. For these reasons, ir the following discussion, "aerial photography" also may be read as "satellite images."

Aerial photographic surveys should be made of each glacierized region of the United States. Witt in each region, specific glaciers will be identified for aerial survey. The selected glaciers will represent the range of glaciers that characterize the region and include those that present hazards, such as icedammed lakes, or those of glaciological interest, such as surging glaciers. The inclusion of Benchmark and secondary glaciers in the aerial surveys will link the known processes controlling mass balance and resulting variations with glacier variations observed across the region. Aerial surveys should be flown late in the summer so the terminus will be in its most retracted position; the transient snowline nearest its final, seasonal position; and the accumulation-area ratio at its seasonal minimum. The interval between photographic surveys will depend on the rates and magnitude of glacier changes in each region and the importance of coverage. For example, the terminus position of a tidewater glacier undergoing catastronhic retreat can change by a kilometer or more per year (Post, 1975), whereas the termini of small cirque glaciers, such as those in Colorado or Montana, might change only a few meters each year. Suggested intervals between aerial photographic surveys are provided in table 1.

\section{Primary Measurements}

Specific attributes, which include glacier area, terminus position, and snowline, will be identified on selected glaciers of each region. From these data. the accumulation-area ratio will be calculated. This information will be used to develop and evaluate the relation of variations of the Benchmark and secon tary glaciers to regional glacier variations. The

Benchmark and secondary glaciers then can be used as predictors of regional glacier change for quantifying the effect of glaciers on water resources.

\section{Supplementary Data}

If photographs or images are of suitable quality, then it is desirable to determine the surface elevation 
Table 1. Frequency of aerial photographic surveys for glacierized mountain regions of the United States

\begin{tabular}{lc}
\hline \multicolumn{1}{c}{$\begin{array}{c}\text { Geographic region } \\
\text { (fig. 4) }\end{array}$} & $\begin{array}{c}\text { Flight interval } \\
\text { (years) }\end{array}$ \\
\hline Alaska & 1 \\
Southeast Panhandle & 1 \\
Wrangell-St. Elias Range & 1 \\
Chugach and Kenai Ranges & $2-3$ \\
Alaska Range & 10 \\
Brooks Range & \\
Washington and Oregon: & $2-3$ \\
$\quad$ Olympic and Cascade Ranges & 10 \\
California & \\
$\quad$ Sierra Nevada & 10 \\
Colorado & \\
$\quad$ Front Range & 10 \\
Montana and Wyoming: & \\
$\quad$ Glacier National Park, Beartooth Mountains, \\
$\quad$ Wind River Range
\end{tabular}

of a number of glaciers (in addition to the Benchmark or secondary networks of glaciers) for calculating volume change. This additional information greatly increases the usefulness of the data by providing an independent check on the mass changes inferred from the accumulation-area ratio.

Satellite images of entire glacierized regions should be obtained once every decade with more frequent coverage of regions in which changes are rapid, such as the tidewater glaciers of southern coastal Alaska. Imagery should have sufficient resolution to show the small glaciers in the region. Like aerial photographs, the images should be obtained late in the summer near the time when the greatest area of snow-free ice is exposed. These images should be analyzed for glacier area and snowline position.

\section{Observation Summary}

Mass Balance

- Accumulation-area ratio

Geometry

- Glacier area

- Terminus position

Supplementary data

- Glacier surface elevation

- Satellite images covering the entire region

\section{Reports}

Reports on the Remote-Sensing Inventory will include a brief flight summary of the mapped flight lines, a list of glaciers photographed, camera position (vertical or oblique), and part of each glacier photographed if coverage is incomplete. The glaciologic data for each selected glacier within each region will be included in tables.

\section{SUMMARY}

Glacier change is an important environmental variable that affects global sea level and terrestrial water resources and poses potentially razardous situations. For these reasons, it is important to document changes in glacier cover. Because of the number and wide distribution of glaciers in the Western States, a practical monitoring plan must encompass sufficient detail and broad coverage. To accomplish this goal, the glaciers of the United States were divided into regional groups. Each region should contain a Benchmark Glacier on which the objective is to collect data to define the relations between local climate, glacier mass balance, and glacier extent and basin runoff. Extrapolating the information gained from a Benchmark Glacier to other glaciers in the region with different physiographic characteristics requires that mass-balance data be collected on a few, less intensively studied secondary glaciers. These glaciers may be monitored by the USGS or cooperating institutions. Estimating the degree of variability of glacier changes across a region and identifying potentially hazardous situations will be accomplished by remote sensing. This nested approa $\mathrm{h}$ to glacier studies will provide sufficiently detailed data to understand the physical processes impcrtant in each region and to provide information on how such processes may vary across the region. This strategy will provide the basic data to understant and predict the effects of glaciers on global sea level, water resources, and hydrologic hazards.

\section{REFERENCES CITED}

Benson, C., Harrison, W., Gosink J., Bowling, S., Mayo, L., and Trabant, D.C., 1986, The role of glacierized basins in Alaskan hydrology, in Kane, D.L., eds., Symposium - Cold regions hydrology: American Water Works Association, p. 471-483. 
Bogorodsky, V.V., Bentley, C.R., and Gudmandsen, P.E., 1985, Radioglaciology: Boston, Kluwer Academic Publishers, $148 \mathrm{p}$.

Braithwaite, R.J., and Olsen, O.B., 1988, Effect of glaciers on annual run-off, Johan Dahl Land, South Greenland: Journal of Glaciology, v. 24, no. 117, p. 200-207.

Brown, C.S., Meier, M.F., and Post, A., 1982, Calving speed of Alaska tidewater glaciers, with application to Columbia Glacier: U.S. Geological Survey Professional Paper 1258-C. 13 p.

Campbell, W.J., 1969, Some statistical considerations, in Østrem, G., and Stanley, A.D., eds., Glacier mass balance measurements-A manual for field and office work: Canadian Department of Energy, Mines and Resources 66, $118 \mathrm{p}$.

Cobb, E.D., and Biesecker, J.E., 1971, The national hydrologic benchmark network: U.S. Geological Survey Circular 460-D, 38 p.

Driedger, C.L., and Fountain, A.G., 1989, Glacier outburst floods at Mt. Rainier, Washington State, U.S.A.: Annals of Glaciology, v. 13, p. 51-55.

Fountain, A.G., 1989, The storage of water in, and hydraulic characteristics of, the firn of South Cascade Glacier, Washington State, U.S.A.: Annals of Glaciology, v. 13, p. 69-75.

1992, Subglacial water flow inferred from stream measurements at South Cascade Glacier, Washington, U.S.A.: Journal of Glaciology, v. 38, no. 128 , p. 51-64.

1993, Geometry and flow conditions of subglacial water at South Cascade Glacier, Washington State, U.S.A.-An analysis of tracer injections: Journal of Glaciology, v. 39, no. 131, p. 143-156.

1994. Borehole water-level variations and implications for the subglacial hydraulics of South Cascade Glacier, Washington State, U.S.A.: Journal of Glaciology, v. 40., no. 135, p. 293-304.

Fountain, A.G., and Tangborn, W.V., 1985, The effect of glaciers on streanflow variations: Water Resources Research, v. 21, no. 4, p. 579-586.

Fountain, A.G., Trabant, D.C., Brugman, M.M., Ommanney, C.S., and Monroe, D.S., 1991, Glacier mass balance standards: EOS, American Geophysical Union Transactions, v. 72, no. 46, p. 511-514.

Fountain, A.G., and Vecchia, A.V., 1992, How many ablation stakes are enough?: EOS, American Geophysical Union Transactions, v. 73, no. 43, p. 180.

Furbish, D.J., and Andrews, J.T., 1984, The use of hypsometry to indicate long-term stability and response of valley glaciers to changes in mass transfer: Journal of Glaciology, v. 30, no. 105, p. 199-211.

Goodison, B.E., and Metcalfe, J.R., 1992, Automation of winter precipitation measurements-The Canadian experience: Technical Conference on Instruments and
Methods of Observation, Vienna, Austria, May 11-15, 1992, 81-85 WMO/TD-no. 462.

Haakensen, Niels, 1986, Glacier mapping to confirm results from mass-balance measurements: Annals of Glaciology, v. 8, p. 73-77.

Hodge, S.M., 1976, Direct measurements of basal water pressures-A pilot study: Journal of Glaciology, v. 16, no. 7, p. 205-218.

1979, Direct measurement of basal water pressures-Progress and problems: Journal of Glaciology, v. 23, no. 89, p. 309-319.

Huybrechts, P., De Nooze, P., and Decleir, H., 1989. Numerical modelling of Glacier d'Argentiere and its historic front variations, in Oerlemans, J., ed., Glarier fluctuations and climatic change: Boston, Kluwer Academic Publishers, p. 373-390.

Johannesson, Tomas, Raymond, C.F., and Waddington. E.D., 1989, Time-scale for adjustment of glaciers to changes in mass balance: Journal of Glaciology, v. 35, no. 121, p. 355-369.

Krimmel, R.M., 1989, Mass balance and volume of So'th Cascade Glacier, Washington, 1958-1985, in Oerlemans, J., ed., Glacier fluctuations and climatic change: Boston, Kluwer Academic Publishers, p. 193206.

1993, Mass balance, meteorological conditions, and runoff measurements at South Cascade Glacier, Washington-1992 balance year: U.S. Geological Survey Open-File Report 93-640, 39 p.

Krimmel, R.M., and Tangborn, W.V., 1974, South Cas ade Glacier, the moderating effect of glaciers on runoff, in Proceedings: Western Snow Conference, 42d Annual Meeting, Anchorage, Sept. 10-14, 1974, p. 9-13.

Krimmel, R.M., Tangborn, W.V., and Meier, M.F., 1973. Water flow through a temperate glacier, in Proceedings-The Role of Snow and Ice in Hydrology Symposium: Banff, Canada, 1973, International Association of Hydrological Sciences Publication 107, p. 401-416.

Krimmel, R.M., and Rasmussen, L.A., 1986, Using seauential photography to estimate ice velocity at the terminus of Columbia Glacier, Alaska: Annals of Glaciology, v. 8, p. 117-123.

LaChapelle, Edward, 1962, Assessing glacier mass budgets by reconnaissance aerial photography: Journal of Glaciology, v. 4, no. 33, p. 290-301.

Mayo, L.R., 1972, Self-mixing antifreeze solution for precipitation gages: Journal of Applied Meteorology, v. 11 , no. 2 , p. $400-404$.

1989, Advance of Hubbard Glacier and 1986 outburst of Russell Fiord, Alaska, U.S.A.: Annals of Glaciology, v. 13, p. 189-194.

1992, Internal ablation-An overlooked component of glacier mass balance: EOS, American Geophysical Union Transactions, v. 73, no. 43, p. 180. 
Mayo, L.R., March, R.S., and Trabant, D.C., 1985, Growth of Wolverine Glacier, Alaska, determined from surface altitude measurements, 1974 and 1985: University of Alaska, Institute of Water Resources, Report IWR108, p. 113-121.

Mayo, L.R., Meier, M.F., and Tangborn, W.V., 1972, A system to combine stratigraphic and annual massbalance systems-A contribution to the International Hydrological Decade: Journal of Glaciology, v. 11, no. 61, p. 3-14.

Mayo, L.R., and Trabant, D.C., 1984, Observed and predicted effects of climate change on Wolverine Glacier, Southern Alaska, in McBeath, J.H., ed., The potential effects of carbon dioxide-induced climatic changes in Alaska: Fairbanks, University of Alaska. School of Agriculture and Land Resources Management Miscellaneous Publication 83-1, p. 114-123.

1986, Recent growth of Gulkana Glacier, Alaska Range, and its relation to glacier-fed river runoff, in Subitzky, Seymour, ed., Selected papers in the hydrologic sciences 1986: U.S. Geological Survey Water-Supply Paper 2290, p. 91-99.

McCabe, G.J., and Fountain, A.G., 1995, Relation between atmospheric circulation and changes in South Cascade Glacier, Washington: Arctic and Alpine Research, v. 27, no. 3, p. 226-233.

Meier, M.F., 1958, Research on South Cascade Glacier: The Mountaineer, v. 51, no. 4, p. 40-47. 1962, Proposed definitions for glacier mass budget terms: Journal of Glaciology, v. 4, no. 33, p. 252-263.

1965, Glaciers and climate, in Wright, H.E., and Frey, D.G., eds., The Quaternary of the United States: Princeton, N.J., Princeton University Press, p. 795805.

1966. Some glaciological interpretations of remapping programs on South Cascade, Nisqually, and Klawatti Glaciers, Washington: Canadian Journal of Earth Sciences, v. 3, no. 6, p. 811-818.

1969, Glaciers and water supply: Journal of the American Water Works Association, v. 61, no. 1, p. 8-12.

-1984, Contribution of small glaciers to global sea level: Science, v. 226, p. 1418-1421.

Meier, M.F., and Post, A.S., 1962, Recent variations in mass net budgets of glaciers in western North America. in Proceedings: Obergurgl, Germany, 1962.

Variations of the Regime of Existing Glaciers Symposium, International Association of Hydrological Sciences 58, p. 63-77.

1969, What are glacier surges?: Canadian Journal of Earth Sciences, v. 6, no. 4, p. 807-817.

Meier, M.F., and Roots, E.F., 1982, Glaciers as a water resource: Nature and Resources, v. 18, no. 3 . p. 7-14.
Meier, M.F., and Tangborn, W.V., 1961, Distinctive characteristics of glacier runoff: U.S. Geological Survey Professional Paper 424-B, p. R14-B16.

1965, Net budget and flow of South Cascade Glacier, Washington: Journal of Glacislogy, v. 5, no. 41 , p. 547-566.

Meier, M.F., Tangborn, W.V., Mayo, L.R., and Post, A.S., 1971. Combined ice and water balances of Gulkana and Wolverine Glaciers, Alaska, and south Cascade Glacier, Washington, 1965 and 1966 hydrologic years: U.S. Geological Survey Professional Faper 715-A, $23 \mathrm{p}$.

Meier, M.F., Rasmussen, L.A., Krimmel, R.M., Olsen, R.W., and Frank, D., 1985, Photographic determination of surface altitude, terminus position, and ice velocity of Columbia Glacier, Alaska: U.S. Geological Survey Professional Faper 1258-F, $41 \mathrm{p}$.

Meierding, T.C., 1982, Late Pleistocene glccial equilibrium-line altitudes in the Colorado Front Range-A comparison of methods: Quaternary Research, v. 16, p. 289-310.

Moss, M.E., and Lins, H.F., 1989, Water re ources in the twenty first century-A study of the implications of climate uncertainty: U.S. Geological Survey Circular $1030,25 \mathrm{p}$.

O'Connor, J.E., and Costa, J.E., 1993, Geologic and hydrologic hazards in glacierized basins in North America resulting from 19 th and 20th century global warming: Natural Hazards, v. 8, p. 121-140.

Oerlemans, J., and Fortuin, J.P.F., 1992, Se nsitivity of glaciers and small ice caps to greenhouse warming: Science, v. 258, p. 115-117.

Osterkamp, W.R., Hupp, C.R., and Blodgett, J.C., 1986, Magnitude and frequency of debris flo'vs, and areas of hazard on Mount Shasta, northern California: U.S. Geological Survey Professional Paper 1396-C, $21 \mathrm{p}$.

Osterkamp, W.R., and Parker, R.S., 1991, Sediment monitoring in the United States, in Far, S., and Kuo, Y., eds., Proceedings: Federal Interagency Sedimentation Conference, 5th, 1991, Las Vegas p. 115-129.

Østrem, G., and Brugman, M., 1991, Glacier mass-balance measurements: Environment Canada, National Hydrology Research Institute, Science Report 4, 224 p.

Paterson, W.S.B., 1981, The physics of glaciers, (2d ed.): New York, Pergamon Press, 380 p.

Pierce, K.L., 1979, History and dynamics of glaciation in the northern Yellowstone National Fark area: U.S. Geological Survey Professional P-per 729-F, $90 \mathrm{p}$.

Porter, S.C., 1977, Present and past glaciation thresholds in the Cascade Range, Washington, U.S.A.-Topographic and climatic controls and paleoclimatic 
implications: Journal of Glaciology, v. 18, no. 78, p. 101-116.

Porter, S.C., Pierce, K.L., and Hamilton, T.D., 1983, Late Pleistocene glaciation in the Western United States, in Porter, S.C., ed., Late Quaternary environments of the United States: Minneapolis, University of Minnesota Press, p. 71-111.

Post, A.S., 1975, Preliminary hydrography and historic terminal changes of Columbia Glacier, Alaska: U.S. Geological Survey Hydrologic Investigations Atlas HA-559, 3 sheets, scale 1:10,000.

Post. A.S., and Mayo, L.R., 1971, Glacier dammed lakes and outburst floods in Alaska: U.S. Geological Survey Hydrologic Investigations Atlas HA-455, 3 sheets, scale 1:1,000,000.

Rasmussen, L.A., 1988, Bed topography and mass-balance distribution of Columbia Glacier, Alaska, U.S.A., determined from sequential aerial photography: Journal of Glaciology, v. 34, no. 117, p. 208-216.

Rodbell, D.T., 1992, Late Pleistocene equilibrium-line reconstructions in the northern Peruvian Andes: Boreas, v. 21, p. 43-52.

Röthlisberger, H., 1972, Water pressure in intra- and subglacial channels: Journal of Glaciology, v. 11, no. 62 , p. $177-213$.

Snyder, E.F., 1996, Bibliography of glacier studies by the U.S. Geological Survey: U.S. Geological Survey Open-File Report 95-723, 32 p.

Tangborn, W.V., 1980, Contribution of glacier runoff to hydroelectric power generation on the Columbia River, in Data of glaciological studies: Proceedings of the International Symposium on Computation and Forecasts of the Runoff from Glaciers and Glacierized Areas, Academy of Sciences of the USSR, Section of Glaciology of the Soviet Geophysical Committee and Institute of Geography Publication 39, p. 62-67; p. 140-143.

Tangborn, W.V., Fountain, A.G., and Sikonia, W.G., 1990, Effect of area distribution with altitude on glacier mass balance-A comparison of North and South Klawatti Glaciers, Washington State, U.S.A.: Annals of Glaciology, v. 14, p. 278-282.
Tangborn, W.V.. Krimmel, R.M., and Meier, M.F., 1975, A comparison of glacier mass balance by glaciological hydrological, and mapping methods, South Cascade Glacier, Washington, in Snow and Ice Symposium, Moscow, 1971, Proceedings: International Association of Hydrological Sciences 104, p. 185-196.

Trabant, D.C., and Mayo, L.R., 1985, Estimation and effects of internal accumulation on five glaciers in Alaska: Annals of Glaciology, v. 6, p. 113-117.

United Nations Educational, Scientific, and Cultural Organization/International Association of Hydrological Sciences [UNESCO/IASH], 1970, Combined heat, ice and water balances at selected glacier basins: Paris, UNESCO, Technical Papers in Hydrology 5, 20 p.

U.S. Geological Survey, 1986, Water Resources Division in the 1980's: U.S. Geological Survey Circular 1005, $80 \mathrm{p}$.

Walder, J.S., and Driedger, C.L., 1994, Geomorphic change caused by outburst floods and debris flows at Mount Rainier, Washington with emphasis on Tahoma Creek Valley: U.S. Geological Survey Water-Resources Investigations Report 93-4093, 93 p.

Walters, R.A., and Meier, M.F., 1989, Variability of glacier mass balances in western North America: American Geophysical Union Geophysical Monograph 55, p. 365-374.

Watts, R.D., and Wright, D.L., 1981, System for measuring thickness of temperate and polar ice from the ground or from the air: Journal of Glaciology, v. 27, no. 97, p. $459-469$.

Waythomas, C.F., 1990, Quaternary geology and lateQuaternary environments of the Holitna lowland and Chuinuk-Kiokluk Mountains region, interior southwestern Alaska: Boulder, University of Colorado, Ph.D. dissertation, 268 p.

Williams, R.S., Jr., Hall, D.K., and Benson, C.S., 1991, Analysis of glacier facies using satellite techniques: Journal of Glaciology, v. 37, no. 125, p. 120-128. 